\title{
A case control study to evaluate correlation of anemia with severe preeclampsia
}

\section{Garima Gupta*}

Department of Obstetrics and Gynecology, Gandhi Medical College, Bhopal, Madhya Pradesh, India

Received: 03 May 2018

Accepted: 29 May 2018

\section{*Correspondence:}

Dr. Garima Gupta,

E-mail: nagsgarima@gmail.com

Copyright: () the author(s), publisher and licensee Medip Academy. This is an open-access article distributed under the terms of the Creative Commons Attribution Non-Commercial License, which permits unrestricted non-commercial use, distribution, and reproduction in any medium, provided the original work is properly cited.

\begin{abstract}
Background: Preeclampsia is a leading cause of maternal and perinatal morbidity and mortality worldwide. This study aims to evaluate correlation of anemia with severe preeclampsia.

Methods: It is a prospective case control study conducted in Sultania Zanana Hospital, Bhopal over one year period. Patients were grouped as cases (severe preeclampsia with severe anemia, $n=180$ ) and controls (severe preeclampsia with no/mild/moderate anemia, $\mathrm{n}=180$ ). Collecting data were compared using the Pearson chi square, fisher's exact test and the independent t-test as appropriate. Logistic regression analysis was performed. Odds ratio (OR) and their corresponding $95 \%$ confidence intervals were calculated.

Results: Higher incidence of maternal complications abruption (8.88\% v/s 0.5\%), ARF (2.2\% v/s 0.5\%), PPH (2.8\%), pulmonary edema $(5 \%)$, CCF $(3.3 \%)$, HELLP (1.6\%), CVA (1.1\%), pulmonary embolism and DIC in $0.5 \%$ and maternal mortality seen in cases. Perinatal complications like pregnancy wastage $(22.8 \% \mathrm{v} / \mathrm{s} 7.8 \%)$, IUGR $(55.8 \% \mathrm{v} / \mathrm{s}$ $32 \%)$, early neonatal death $(7.5 \%$ v/s $2.4 \%)$, NICU admission (31.3\% v/s $20.7 \%)$ were more in cases.

Conclusions: Perinatal and maternal complications are significantly associated with severity of anemia in preeclampsia women. Anemia being a easily detectable and modifiable risk factor, detection of anemia in early gestation can be a key to prevent or decrease the severity of preeclampsia.
\end{abstract}

Keywords: Acute renal failure, Anemia, Preeclampsia, Small for date

\section{INTRODUCTION}

Hypertensive disorders of pregnancy and their complications rank as one of the major cause of maternal mortality and morbidity in the world. Amongst them, preeclampsia is emerging as one of the most common complication of pregnancy.

Pre-eclampsia is a multi-system disorder of unknown aetiology, unique to pregnancy, with onset after 20 weeks of gestation.

Although, the exact aetiology of preeclampsia is not yet known, many factors such as low education, prim parity, family history of hypertension, obesity, younger and advanced maternal age and malnourishment are proven as its risk factors and evidence suggests that various other factors like severe anemia could also be a risk factor for development of preeclampsia and that cannot be ignored.

The uncertainty of cause of a disease of such common occurrence worldwide, make it to be more studied. Several studies have shown the association between severe anemia and preeclampsia and thus considers anemia as one of the main and treatable risk factor for preeclampsia.

Anemia during pregnancy is a major public health problem especially in developing countries which itself increases the maternal mortality, in addition it further 
adds to the maternal and perinatal morbidity associated with preeclampsia, being a risk factor. It affects $41.8 \%$ women globally. In India overall prevalence of anemia is $65-70 \%$ and it contributes to $40 \%$ maternal deaths.

Although preeclampsia is not a preventable disease but by putting light on the modifiable risk factors which play a role in its aetiology and which are amenable to get treated, the incidence of preeclampsia can be decreased. Thus identification of reversible factors such as anemia in pregnancy which is a treatable condition will be of great help for policy making and clinical purpose such as prioritization of interventions so that more intensive observation and improvement of risk management strategies can be done.

\section{METHODS}

The present study is a prospective case-control study conducted among pregnant women admitted in Sultania Zanana Hospital, Bhopal. Data were collected from all Antenatal cases with gestational age $\geq 20$ weeks between $18 \mathrm{yrs}$ and $40 \mathrm{yrs}$ of age as per the inclusion and exclusion criteria admitted under OBG department, SZH Bhopal.

Inclusion criteria were all severe preeclampsia women of age between 18-40 years were enrolled in this study and divided into following groups:

- Group 1- severe preeclampsia with severe anemia (Cases)

- Group-2- severe preeclampsia with no/mild/moderate anemia (Controls)

The two groups were matched according to parity. All women were followed until delivery and early postpartum period and babies till early neonatal period.

Exclusion criteria included pregnant women withessential hypertension/hypertension < 20 weeks gestation/ pre-existing diabetes mellitus/renal disease/liver disorder/ thyroid disorder.

Sampling was done using case-control incidence density sampling i.e. cases were enrolled consecutively as they were diagnosed to have severe preeclampsia with severe anemia until the required sample size was obtained. For each case, one control was selected as soon as the case was diagnosed.

Data retrieved included socio-demographic characteristic (age, residence, education), maternal outcome (eclampsia, heart failure, DIC, pulmonary embolism, pulmonary edema, haemorrhage), and neonatal outcome (preterm birth, still birth, low birth weight).

Collected data were entered into Microsoft excel spreadsheet and were analysed by using SPSS20.0 Software. Comparison between categorical variable were made using the Pearson chi square and Fisher's exact test as appropriate, and between quantitative variable using the independent t-test. Logistic regression analysis was performed. Odds ratio (OR) and their corresponding 95\% confidence intervals were calculated. $\mathrm{P}$ value $<0.05$ was regarded as significant.

\section{RESULTS}

The present study was carried out in Department of Obstetrics and Gynaecology, Sultania Zanana Hospital during the period $1^{\text {st }}$ March 2015 to $29^{\text {th }}$ February 2016. Total no. of deliveries in $\mathrm{SZH}$ during this period was 14029. Number of preeclampsia cases admitted during this period 818. Thus incidence of Preeclampsia comes about $5.8 \%$.

Most of the cases as well as controls were found to be of age group 21-30 yrs. Mean age of women among the cases was 24.98years (SD 4.155) and of control was 25.57 years (SD 3.871) . Out of the 180 cases maximum i.e. $42 \%$ were illiterate while among 180 controls, $30 \%$ were illiterate. In present study, among the cases $81 \%$ presented at term pregnancy while $19 \%$ were preterm pregnancies. In controls, $78 \%$ presented at term and $22 \%$ were preterm .There is no significant difference between the gestational age among the cases and control, at which they presented.

Table 1: Mode of delivery.

\begin{tabular}{|c|c|c|c|}
\hline $\begin{array}{l}\text { Mode of } \\
\text { delivery }\end{array}$ & Case & Control & $\begin{array}{l}\text { Chi } \\
\text { square }\end{array}$ \\
\hline FTVD & $117(65 \%)$ & $117(65 \%)$ & \multirow{4}{*}{$\begin{array}{l}2.154, \\
\mathrm{P}=0.341, \\
\mathrm{NS}\end{array}$} \\
\hline PTVD & $35(19.5 \%)$ & $43(24 \%)$ & \\
\hline LSCS & $28(15.5 \%)$ & $20(11 \%)$ & \\
\hline Total & $180(100 \%)$ & $180(100 \%)$ & \\
\hline
\end{tabular}

As observed in Table 1, out of 180 cases $65 \%$ had full term vaginal delivery, $19.5 \%$ had preterm vaginal delivery, and $15.5 \%$ landed up in caesarean section. Most common indication of caesarean was fetal distress $\mathrm{f} / \mathrm{b}$ previous LSCS $\mathrm{f} / \mathrm{b}$ malpresentation. In controls maximum had vaginal deliveries, $65 \%$ had full term while $24 \%$ had pre term vaginal deliveries while $11 \%$ had caesarean section. Most common indication of caesarean was fetal distress. There is no much difference in the mode of delivery among cases and controls.

Table 2: Maternal outcome.

\begin{tabular}{|llll|}
\hline $\begin{array}{l}\text { Maternal } \\
\text { outcome }\end{array}$ & Case & Control & $\begin{array}{l}\text { Fisher's } \\
\text { exact test }\end{array}$ \\
\cline { 1 - 3 } Discharged & $\begin{array}{l}156 \\
(86.7 \%)\end{array}$ & $\begin{array}{l}179 \\
(99.44 \%)\end{array}$ & \\
\cline { 1 - 3 } Mortality & $9(5 \%)$ & 0 & $\begin{array}{l}24.815, \\
\mathrm{P}=<0.001,\end{array}$ \\
\cline { 1 - 3 } Transferred & $\begin{array}{l}15 \\
(8.3 \%)\end{array}$ & $\begin{array}{l}1(0.56 \%) \\
\text { S }\end{array}$ \\
\cline { 1 - 3 } Total & $\begin{array}{l}180 \\
(100 \%)\end{array}$ & $\begin{array}{l}180 \\
(100 \%)\end{array}$ \\
\hline
\end{tabular}


Table 2 shows the maternal outcome. In this study maternal outcome was significantly poor among the cases. 5\% mortality reported in case group and none in the control group.

All mortalities were due to complications contributed to severity of preeclampsia. 15 patients of 180 cases were transferred to other department due to adverse outcome.

Table 3: Maternal complications.

\begin{tabular}{|llll|}
\hline Complication & Case & Control & P value \\
\hline Abruption & $\begin{array}{l}16 \\
(8.88 \%)\end{array}$ & $1(0.5 \%)$ & $<0.001, \mathrm{~S}$ \\
\hline $\begin{array}{l}\text { Pulmonary } \\
\text { edema }\end{array}$ & $9(5 \%)$ & 0 & $0.002, \mathrm{~S}$ \\
\hline PPH & $5(2.8 \%)$ & 0 & $0.024, \mathrm{~S}$ \\
\hline CCF & $6(3.3 \%)$ & 0 & $0.013, \mathrm{~S}$ \\
\hline ARF & $4(2.2 \%)$ & $1(0.5 \%)$ & $0.176, \mathrm{NS}$ \\
\hline HELLP & $3(1.6 \%)$ & 0 & $0.081, \mathrm{NS}$ \\
\hline Eclampsia & $3(1.6 \%)$ & $12(6.6 \%)$ & $0.017, \mathrm{~S}$ \\
\hline CVA & $2(1.1 \%)$ & 0 & $0.156, \mathrm{NS}$ \\
\hline $\begin{array}{l}\text { Pulmonary } \\
\text { embolism }\end{array}$ & $1(0.5 \%)$ & 0 & $0.316, \mathrm{NS}$ \\
\hline DIC & $1(0.5 \%)$ & 0 & $0.316, \mathrm{NS}$ \\
\hline
\end{tabular}

Table 3 shows that all maternal complications were significantly higher among the cases, except eclampsia which was surprisingly more seen among the controls.

The odds ratio calculated for maternal complication $(\mathrm{OR}=3.836,95 \% \mathrm{CI}: 2.017-7.295)$ suggest that odds of maternal complication in women with severe preeclampsia with severe anemia is 3.83 times more than controls, and the result is significant $(\mathrm{p}<0.001)$. However, the effect of mild/moderate anemia cannot be ignored.

Table 4: Fetal outcome.

\begin{tabular}{|c|c|c|c|}
\hline Viability & Case & Control & Chi square \\
\hline Alive & $\begin{array}{l}147 \\
(78.2 \%)\end{array}$ & $\begin{array}{l}169 \\
(92.3 \%)\end{array}$ & \multirow{3}{*}{$\begin{array}{l}14.721, P= \\
<0.001, S\end{array}$} \\
\hline SB/IUD & $\begin{array}{l}41 \\
(21.8 \%)\end{array}$ & $14(7.7 \%)$ & \\
\hline Total & $\begin{array}{l}188 \\
(100 \%)\end{array}$ & $\begin{array}{l}183 \\
(100 \%)\end{array}$ & \\
\hline
\end{tabular}

Table 4 shows the fetal outcome in cases and controls. Pregnancy wastage in cases were $22.8 \%$ while in controls were $7.8 \%$. This suggests poor fetal outcome among the cases which was statistically significant. $\mathrm{OR}=3.3669$ (95\% CI, 1.765-6.421).

Odds of having still birth is 3.3 times higher in cases than controls and the result is significant $(p<0.001)$. The majority of deaths were due to abruptio placenta. Other causes were non-viable pregnancy, severe IUGR, and prematurity.
Table 5: Perinatal outcome.

\begin{tabular}{|c|c|c|c|}
\hline $\begin{array}{l}\text { Perinatal } \\
\text { outcome }\end{array}$ & Case & Control & $\begin{array}{l}\text { Chi } \\
\text { square }\end{array}$ \\
\hline $\begin{array}{l}\text { Term } \\
\text { appropriate } \\
\text { for date }\end{array}$ & $\begin{array}{l}64 \\
(43.5 \%)\end{array}$ & $\begin{array}{l}103 \\
(60.9 \%)\end{array}$ & \multirow{5}{*}{$\begin{array}{l}32.6933, \\
P<0.001, S\end{array}$} \\
\hline $\begin{array}{l}\text { Term small } \\
\text { for date }\end{array}$ & $\begin{array}{l}71 \\
(48.3 \%)\end{array}$ & $\begin{array}{l}34 \\
(20.1 \%)\end{array}$ & \\
\hline $\begin{array}{l}\text { Pre term } \\
\text { appropriate } \\
\text { for date }\end{array}$ & $1(0.7 \%)$ & $12(7.1 \%)$ & \\
\hline $\begin{array}{l}\text { Pre term small } \\
\text { for date }\end{array}$ & $\begin{array}{l}11 \\
(7.5 \%)\end{array}$ & $\begin{array}{l}20 \\
(11.9 \%)\end{array}$ & \\
\hline Total & $\begin{array}{l}147 \\
(100 \%)\end{array}$ & $\begin{array}{l}169 \\
(100 \%)\end{array}$ & \\
\hline
\end{tabular}

Table 6: Neonatal mortality.

\begin{tabular}{|c|c|c|c|}
\hline $\begin{array}{l}\text { Early } \\
\text { neonatal } \\
\text { death }\end{array}$ & Case & Control & Chi square \\
\hline Present & $11(7.5 \%)$ & $4(2.4 \%)$ & \multirow{3}{*}{$\mathrm{P}=0.032, \mathrm{~S}$} \\
\hline Absent & $\begin{array}{l}136 \\
(92.5 \%)\end{array}$ & $\begin{array}{l}165 \\
(97.6 \%)\end{array}$ & \\
\hline Total & $\begin{array}{l}147 \\
(100 \%)\end{array}$ & $\begin{array}{l}169 \\
(100 \%)\end{array}$ & \\
\hline
\end{tabular}

Table 5 shows that in our study, out of total live births in cases $43.5 \% \%$ were term appropriate for date, $48.3 \% \%$ term small for date, and $7.5 \% \%$ were preterm SFD, while among the controls maximum i.e. $60.9 \%$ were TAFD, which shows that chances of IUGR are more among the cases which is statistically significant.

As observed in Table 6, In this study, out of total 147 live births among cases, $11(7.5 \%)$ succumb to early neonatal death that was significantly more than the controls i.e. 4 $(2.4 \%)$ out of 169 live births. Most common cause of death was perinatal asphyxia.

The odds of early neonatal death for cases is 3.33 times higher than controls (OR 3.336, 95\% CI (1.038-10.714) the result is significant $(\mathrm{p}=0.03)$.

\section{DISCUSSION}

Thus incidence of preeclampsia in Sultania Zanana Hospital is 5.8\%. Jaiprakash et al found the similar result of incidence i.e. $5.8 \%, 5.8 \%$ reported from a study in Scotland. ${ }^{1}$ Mudaliar and Menon has noted incidence of preeclampsia between $7-9 \%$ in Indian studies. ${ }^{2}$ Preeclampsia affects approximately $2-8 \%$ of all pregnancies worldwide. ${ }^{3}$

In this study the mean age of study population is 25.28 years. Advanced maternal age has been found to be an independent risk factor for preeclampsia, while in this study most of the cases and controls were in the age 
group 21-30 years, which is probably because in our population early marriage is more common. Jaiprakash et al found the mean age of patients was $26.6 \pm 5$ years. ${ }^{1}$ Enaruna et al found 30 years (range: 19 to 41) and Assis et al found that age above 30 years was associated with a risk for preeclampsia., ${ }^{4,5}$ Andhra Pradesh found the highest prevalence of anaemia $(68.4 \%)$ in the age group 20-24 years. There has been increased risk of anaemia among pregnant adolescents (teenage pregnancy) due to depleted iron stores that occurred during the adolescent growth spurt.

This study shows that out of 180 cases $42 \%$ had no formal education as compare to controls in which $30 \%$ were illiterate. It suggests that women with lower education level were more likely to develop preeclampsia as well as severe anemia as compared to controls. Tebeu et al found that illiteracy was associated with about 2 -fold risk for presenting hypertensive disorder in pregnancy (OR: $1.7 ; 95 \%$ CI: 1.1-2.4). ${ }^{6}$

Out of 180 cases $94.4 \%$ were referred from other hospital, $3.9 \%$ were not referred and $1.7 \%$ were booked at SZH. Among controls $81.7 \%$ were referred, $13.3 \%$ were not referred and 5\% were booked at SZH .Boniface et al reported that obstetric risks were more in un-booked pregnant women compared to booked ones. ${ }^{7}$ The booked patient benefits from focused antenatal care objectives, which have obvious benefits in terms of risk assessment, active management, correction of modifiable conditions, and boosting the psychological support and family preparedness for a new child.

These result shows that compared with control significantly higher numbers of cases were resident of rural area, had lower level of education and were referred from other hospitals. This indicates that women from rural area may not afford or have access to good maternal health care services because of lack of education or financial constraints.

In our study, maximum no. of cases i.e. $81 \%$ as well as controls i.e. $78 \%$ presented at term pregnancies. While $8 \%$ cases and $7 \%$ controls presented at 28-32 weeks of gestation. And $11 \%$ cases and $14 \%$ cases presented at 33-36 wks of gestation, which shows no statistical significance. Cheema et al observed higher prevalence of anemia in $3^{\text {rd }}$ trimester. $^{8}$ Jaiprakash et al found approximately half of $47.16 \%$ of the preeclamptic women were at 32-36 wks of gestation period, $15.09 \%$ were at $<32$ weeks and $26.41 \%$ were at $>36$ weeks. ${ }^{1}$ Anemia leads to increased synthesis of corticotrophinreleasing hormone $(\mathrm{CRH})$ as a result of tissue hypoxia. These raised levels can induce maternal and fetal stress, and thus produce a risk factor for preterm labour.

Present study shows that, $84.5 \%$ cases undergone vaginal deliveries and $15.5 \%$ cases were resorted to LSCS, $63.9 \%$ patients went in spontaneous labour while rest were induced While among controls rate of vaginal deliveries was $89 \%$ and of LSCS was $11 \%$ and $77.8 \%$ went in spontaneous labour while $22.2 \%$ were induced. Aabidha et al observed $58 \%$ of the patients were induced and $45 \%$ needed caesarean section due to obstetric indication in severe preeclampsia patients. ${ }^{9}$

Present study shows, out of 180 cases, 8 were twin pregnancy and among 180 controls, 3 were twins. Proportion of dead fetus was more in cases as compare to controls i.e. $21.8 \%$ versus $7.7 \%$. This suggests poor fetal outcome in cases.

Aabidha et al, found $10 \%$ stillbirths in patients with severe preeclampsia. ${ }^{9}$ The higher proportion of SB in our study shows impact of severe anemia on severe preeclampsia. Severe preeclampsia represents significant risk factor for intrauterine fetal demise, with estimated stillbirth rate of 21 per $1000 .{ }^{10}$

Present study shows that Women with severe anemia delivered infants with a significantly lower birth weight than women in control group. In cases the proportion of extremely low birth weight, very LBW and LBW is significantly higher than controls $(13.3 \%$ versus $3.3 \%$, $10.1 \%$ versus $8.2 \%$ and $58.5 \%$ versus $50.3 \%$ ). Low birth weight, i.e. $2.5 \mathrm{Kg}$ is widely used as an indicator of newborn health. Jones et al also found an increased incidence of low birth weight babies in anaemic mothers, however the difference from the non anaemic group in their study was non significant $(\mathrm{p}=0.11)$

Present study shows, $55.8 \%$ of 147 live birth babies in cases were IUGR as compare to $31.9 \%$ of 169 live birth in controls. Of 147 live born in cases, 46 (31.3\%) were admitted in NICU whereas NICU admission rate was $20.7 \%$ in controls.

Among the cases $11(7.5 \%)$ neonate succumb to early neonatal death as compared to controls $(2.4 \%)$. Nirmala Devi et al found IUGR in $12.77 \%$ patients of severe anemia. ${ }^{11}$ Swamy et al observed perinatal and neonatal mortality rates were 13.83 and $6.49 \%$, respectively in severe preeclampsia cases. ${ }^{12}$ Enaruna et al observed stillbirth (32.8\% more) and ENND (13.8\% more) were significantly associated with severe anemia in severe preeclampsia cases. ${ }^{4}$ Liu et al observed the proportion of babies who stayed alive up to 7 days after delivery was significantly reduced by the presence of severe anemia. ${ }^{13}$

The increased incidence of perinatal morbidity and mortality seen in pregnancies complicated by preeclampsia, is due to the need for premature delivery and utero-placental insufficiency resulting in compromised blood supply to the fetus but presence of severe anemia contribute to adverse outcome of severe preeclampsia .

In this study the maternal outcome in majority of patients in control group was normal i.e. the patient was 
discharged in a satisfactory condition However outcome was significantly poor among the cases.

Out of 180 cases, $9(5 \%)$ deaths were recorded in this study and 15 patients $(8.3 \%)$ were transferred to other department due to adverse outcome. 3 deaths were due to pulmonary edema, 2 due to $\mathrm{CCF}, 1$ due to pulmonary embolism, 1 due to PPH, 1 due to CVA and 1 due to HELLP leading to ARF. Enaruna et al observed that Severe anemia was 7.7-fold more associated with maternal mortality in severe preeclampsia cases than no anemia. $^{4}$

Abruption was seen in $8.88 \%$ cases than $0.5 \%$ controls, ARF was seen in $2.2 \%$ cases than in $0.5 \%$ control. Pulmonary edema seen in 5\% cases, PPH occurred in $2.8 \%$ cases, CCF in $3.3 \%$, HELLP in $1.6 \%$, CVA $1.1 \%$, Pulmonary embolism and DIC in $0.5 \%$ cases. Whereas none of these complications reported in controls. Singhal et al reported maternal complication as $\mathrm{PPH} 31 \%$, abruption $11 \%$, renal dysfunction $4 \%$, pulmonary edema $8 \%$, pulmonary embolism $8 \%$, HELLP $\%$, DIC $2 \%$, and maternal mortality in $8 \%$ cases of severe preeclampsia which was comparable with this study. ${ }^{14}$

Ndoni et al observed eclampsia 7.1\%, HELLP syndrome $11.0 \%$, stroke $1.9 \%$, pulmonary edema $1.3 \%$, renal failure $2.6 \%$, placental abruption $7.8 \%$, and severe postpartum hemorrhage $3.9 \%$ in severe preeclampsia. ${ }^{15}$.

\section{CONCLUSION}

Anemia and preeclampsia per se causes increased perinatal and maternal morbidity and mortality. Present study analysed the association of anemia with severe preeclampsia it was observed that the risk of perinatal and maternal morbidity and mortality increases with severity of anemia, when associated with preeclampsia. Thus analyzing the obtained result of this study and considering the previous studies, it can be concluded that detection of anemia in early gestation can be a key to prevention of preeclampsia.

\section{Funding: No funding sources}

Conflict of interest: None declared

Ethical approval: The study was approved by the Institutional Ethics Committee

\section{REFERENCES}

1. Prakash J, Vohra R, Pandey LK, Niwas SS, Behura SK, Singh U. Spectrum of kidney diseases in patients with preeclampsia-eclampsia. J Assoc Physicians India. 2010;58:543-6.

2. Mudaliar and Menon. The evaluation of treatment of eclampsia. Brit J Obstet Gynaecol. 1961;68:417.
3. World Health Organization (WHO). World health report 2005: make every mother and child count. Geneva: WHO; 2005: 63

4. Enaruna NO, Sodje JD. Early-Onset Severe Preeclampsia in Nigerian Women: Determining a Balance between Maternal Wellbeing and Fetal Survival in a Resource-Limited Setting. British J Med Med Res. 2015;10(3):1-9.

5. Assis TR, Viana FP, Rassi S. Study on the major maternal risk factors in hypertensive syndromes. Arq Bras Cardiol. 2008;91(1):11-7.

6. Tebeu PM, Foumane P, Mbu R, Fosso G, Biyaga PT, Fomulu JN. Risk factors for hypertensive disorders in pregnancy: a report from the Maroua Regional Hospital, Cameroon. J Reprod Infertil. 2011;12(3):227-34.

7. Ago BU, Abeshi S, Njoku C, Agan TU, Ekabua J. Obstetric outcomes of booked teenage pregnancies at University of Calabar Teaching Hospital, Nigeria. Adolescent Health Med Therap. 2012:3:105-9.

8. Cheema HK, Bajwa BS, Kaur K, Joshi H. Prevalence and possible risk factors of anemia in different trimesters. IJCMR. 2016;3(4):1194-7.

9. Aabidha PM, Cherian AG, Paul E, Helan J. Maternal and fetal outcome in preeclampsia in a secondary care hospital in South India, Christian Fellowship Hospital, Oddanchatram. J Family Med Prim Care. 2015;4(2):257-60.

10. Simpson LL. Maternal medical disease: risk of antepartum fetal death. Sem Perinatol. 2002;26(1):42-50.

11. Devi BN, Varalaxmi B, Jyothirmayi T, Lahari N. Maternal outcome in pregnancy with severe anaemia: Prospective study in a tertiary care hospital in Andhra Pradesh. IOSR-JDMS. 2015;14:06-10.

12. Swamy MK, Kamal P, Shailaja N. Maternal and perinatal outcome during expectant management of severe pre-eclampsia between 24 and 34 wks of gestation. J Obstet Gynaecol India. 2012;62(4):4138.

13. Liu S, Joseph KS, Liston RM, Bartholomew, Walker $\mathrm{M}$, Leon JA, et al. Incidence, risk factors and associated complications of eclampsia. Obstet Gynaecol. 2011;118(5):987-94.

14. Singhal SR, Deepika, Anshu, Nanda N. Maternal and perinatal outcome in severe preeclampsia. JSAFOG. 2009;1(3):25-8.

15. Ndoni E, Hoxhallari R, Bimbashi A. Evaluation of Maternal Complications in Severe Preeclampsia in a University Hospital in Tirana. Macedonian J Med Sci. 2016;4(1):102-6.

Cite this article as: Gupta G. A case control study to evaluate correlation of anemia with severe preeclampsia. Int J Reprod Contracept Obstet Gynecol 2018;7:2773-7. 